\title{
6 ON THE TRANSLATABILITY OF PLACENAMES IN THE WIK REGION, CAPE YORK PENINSULA'
}

\author{
Peter Sutton
}

\section{HISTORY}

In the late 1980s I obtained Australian Research Council and local Wik organisational funding to compile a database of site records from western Cape York Peninsula between the Embley and Edward Rivers, in a project based at the South Australian Museum. The main field data came from myself (mapping from 1976 onwards), David Martin (mapping from 1985) and John von Sturmer (mapping from 1969). Small amounts also came from fieldwork by Roger Cribb and Athol Chase, who mainly mapped in 1985, although Roger returned to focus more on archaeological mapping and site work later. ${ }^{2}$

There has also been further database compilation of mainly new (that is, post-1990) field data, especially from the inland sector, amounting to adding a further $200+$ pages of supplementary site reports to the 1,000 pages already produced. This, like the longer 1990 report, is still under restricted access at the time of writing, because of the role of these documents in the ongoing Wik Native Title Determination Application before the Federal Court. The data have now been massaged into a more widely accessible form, using Access

\footnotetext{
Primary acknowledgements are due to the Wik and Wik-Way peoples of western Cape York Peninsula for their long-standing commitment to collaborative efforts with scholars who have carried out fundamental ethnographic research among them, myself included. Particular thanks are also due to John von Sturmer and David Martin for sharing major cultural mapping data from which I have drawn some parts of this paper.

Funding for the research behind this paper came from the Australian Institute of Aboriginal and Torres Strait Islander Studies, Commonwealth Department of Education, University of Queensland Department of Anthropology and Sociology, Aurukun Shire Council, Aurukun Community Incorporated, Department of Aboriginal Affairs, the Australian Heritage Commission, the Australian Research Council, and the Cape York Land Council.

I thank Jane Simpson and Barry Alpher and Bruce Rigsby for helpful comments on earlier drafts, Luise Hercus for help with comparative data, Flavia Hodges for keeping me writing to a fierce deadline, and Michael Walsh for stimulating me in email conversations to think about the byzantine topic of translatability in Aboriginal placenames.

2 At the end of that ARC project the work was produced as Sutton et al. (1990).
}

L. Hercus, F. Hodges and J. Simpson, eds, The Land is a Map: placenames of Indigenous origin in Australia, 75-86.

Canberra: Pandanus Books in association with Pacific Linguistics, 2002.

(C) Peter Sutton 
for the information and a Geographic Information System for the site plots. The records have many fields per site and information is in a majority of cases sourced back to a particular set of Aboriginal consultant names and dates, notebook pages, tape tracks and film roll and shot numbers, such that more detail is available offstage. Most of the material in the database is in English, although the original data may have been in several other languages.

There is a separate database report prepared for the Wik Native Title case by John Taylor, who has been mapping since 1969 mainly in the Mitchell-Edward Rivers region, which deals with sites in the southern end of the Wik area.

Once the Wik Native Title case is over we will have to come to a decision about the future of the material. We have clan heads' permission as of 1985 to publish the 1990 version that was being drafted at that time. We may or may not have to renegotiate that permission.

I am, however, able to briefly outline the nature of this mapping research archive. On a rough count there are about 3,000 site records from approximately 120 clan estates between the Embley and Edward Rivers, and inland to just west of about Coen. Very roughly, around 1,600 of these sites have been visited and ethnographically mapped on the ground. In a number of cases this involved reconstructing specific camps or events and their personnel, remembered from times past by those who were there. We often recorded remains of material culture and routinely focused on economic resource aspects of sites, their seasonal use, camp type, plants found there or nearby, historical memories of the place, religious significance of the place, camp composition and hearth arrangements, ownership matters, restrictions on behaviour, movement pathways between sites, foraging ranges from base-camps, and so on.

Our botanical specimens are now stored at the Queensland Herbarium. These include some exhaustive collecting transects across a range of typical environmental types, plotted onto airphotos. The collecting and ethnobotany of a number of species were carried out opportunistically by most of us, but there was at least one field trip where ecologist Dermot Smyth and I concentrated more or less exclusively on the ethnobotany of the area between the Archer and Kendall Rivers, and Dermot has also done some independent work in the area. ${ }^{3}$

The relation of sites to estates was often focal to this research. Estate descriptions and tenure histories vary in detail from very little to a great deal. These site-based bodies of data cross-link to genealogies covering about 100 estate groups, and to land tenure studies by von Sturmer and myself. ${ }^{4}$

On top of all this is a large multi-volume report currently in the Federal Court, which contains the items listed below under Sutton (1997). Together with the 1990 volume, also in evidence, these reports total about 1,800 pages.

Besides these reports, there are various digitised bodies of material, including mission personal record cards which have been keyboarded, a Wik ethnobotany database by myself and Dermot Smyth, a genealogy database in Brother's Keeper, researchers' own word-processed field note material, audio tape catalogues at the Australian Institute of Aboriginal and Torres Strait Islander Studies, and so on.

Time, space and legalities do mean, however, that here I am able only to take a 'tip of the iceberg' approach.

\footnotetext{
3 I have never had the funded time to write the ethnobotanical material up in detail, although an abbreviated version is sprinkled through my Wik-Ngathan Dictionary (1995).

4 Von Sturmer (1978), Sutton (1978).
} 


\section{COMPLICATIONS}

Placenames in the Wik region seem to offer endless complications. This becomes much clearer as one tries to go through lists of site names and, as I have tried to do, allocate them on a percentage basis to simple dichotomies such as:

$\begin{array}{ll}\text { 'translatable' } & \text { 'untranslatable' } \\ \text { 'archaic word' } & \text { 'contemporary word' } \\ \text { 'original language' } & \text { 'introduced language' } \\ \text { 'autochthonous language' } & \text { 'other Aboriginal language(s)'. }\end{array}$

One complication, for example, lies in the fact that in different languages, and sometimes even in the same language, a site may have both an opaque (untranslatable) name and a translatable name - so does one count this as one of each or one half each for the two categories? And where a site has two or more opaque names, one each in different languages, should one count this as one case of opacity or as two, three etc.? A notable example is the small lagoon and important base camp site of Aayk $=$ Thuul $=$ Thutulu just inland from Cape Keerweer.

A sub-complication for this part of the discussion is that it is clear in some instances that the opaque name is old and endogenous and the transparent name is very probably recent and exogenous. For example, there are cases in the area between the Archer and Embley Rivers where an old opaque name in the local language (Andjingith, Adithinngithigh etc.) is matched and in some cases now replaced by a Wik-Mungkan name meaning '[So-and-so] Story Place'. Thus the Wik name is not a translation of a former site name but its semantic content depends on the pre-existing cultural content of the site itself.

For example:

Iwiken (Adithinngithigh, no translation available) = Pach-aw (Wik-Mungkan) '[Shooting] Star Story Place'

Puk-aw (Wik-Mungkan) 'Baby Story Place' (no original Ndrra'ngith [?] name recorded, perhaps lost)

Uk-aw (Wik-Mungkan) 'Brown Snake Story Place' (no original Andjingith name recorded, perhaps lost)

These are a bit reminiscent of those Australian-English placenames, like Emu Creek, Kangaroo Rock, The Twins, and so on, which in some cases can be shown to be actually based on the presence of the relevant Dreamings, but this is not obvious from the name itself. I have come across many examples over the years. In the case of Lake Cadibarrawirracanna or Kardipirla Warrakanha, 'Star Dancing Place', it is easier for most people when hearing this name to recall Slim Dusty's song about it than to reflect on Australia's original legends.

Certain sites particularly associated with the former Aurukun mission's activities and thus with Europeans - a very small minority of places mostly north of Archer River - are moving towards the loss of their Indigenous names in the Wik area, and a few have already

\footnotetext{
This lake is just east of Coober Pedy. Information and translation from Luise Hercus (pers. comm.).
} 
got there. Among this class of places are Waterfall, Pera Head, ${ }^{6}$ Lowdown Swamp, Mr Little Crossing, Kilpatrick Bill Patrick ${ }^{7}$ Landing, Police Lagoon, and Bamboo. Even further south, younger generations are by now unlikely in most cases to know that the Moving Stone (sometimes Movie Stone, Movie Girl) is at Um Thunth. Even the old name of Thew-en for Cape Keerweer (sometimes Kep Kwiwi, Kek Piwi) is now somewhat antiquarian. But, in general, local placenames have largely endured in the Wik region and north of it to the Embley River.

\section{THE PUZZLE OF LANGUAGE SHIFT}

Nevertheless I have often puzzled over why such language shifts seem to have occurred so rapidly for some placenames, in the face of the strong retention of at least one common Aboriginal language in daily usage in the region. Consider the case of Hagen ${ }^{8}$ Lagoon, the name of an outstation that has been used over a number of years. Even old people who know the lagoon's original name of Ochenganh-thathenh seem to prefer the English name for the outstation. The English name refers to a mission staff member of many years ago who is otherwise little known or remembered. Ochanganh-thathenh means 'saw a mudshell', a far more poetic name.

This anglicisation of placenames has happened with several outstations, including for example Bullyard (Am), Ti Tree (Wanke-niyeng etc.), South Arm (Yaaneng), Emu Foot (Tha' Achemp), ${ }^{9}$ Stony Crossing (Othungam) and North Kendall (Kuchent-eypenh). This may reflect the cultural location of such places on the cusp of local people's interaction with local government and the state, and thus the separation of the outstation name from the original site name in terms of its real denotata. That is, the outstation name is not that of a natural place so much as of an installation and its people. In the case of Aayk, which has operated intermittently as an outstation from 1971 to the time of writing, the outstation name has effectively become separated from the original Aayk, which is a small lagoon, not just semantically but spatially. When the outstation was moved away from this lagoon to be closer to a new dry-weather airstrip at Mulpa'el-nhiin, it became known as 'New Aayk'. And note that this is within a community where the first language of children is still a Wik language.

Wooentoent, for which there is I believe no translation but which is at least euphonious, was in the 1970s being replaced by the imaginative (?) 'Green Point'. Pooerroeth, known in Wik-Mungkan as Piirrith, gave rise to English Peret, the name of a cattle outstation yard and dip, in the $1950 \mathrm{~s}$ or $60 \mathrm{~s} .{ }^{10}$ After a cyclone the residential focus of the cattle operation shifted to the other end of the airstrip, but the buildings retained the name of Peret, until my own residence there brought about a reinstatement of the old name to the new outstation location, Watha-nhiin. Given this means 'white-tailed water rat sitting', its loss would have been regrettable, I thought. The name seems to have retained standing.

\footnotetext{
6 A curious case in that the original name of Malnyinyu seems to have also been in use among the mission staff before the 1960s.

7 From Bill Patridge Landing, see MacKenzie (1981:213).

8 From Jimmy Hogan's Lagoon, see MacKenzie (1981:101).

9 The original placename means literally 'foot emu', i.e. emu's foot.

10 Not to be confused with the late Peret Arkwookerum, whose first name was a rendering of his English pronunciation of the translation of one of his major totems, Parrot.
} 
By the early 1990 s another small settlement had begun back at the other end of the airstrip, but this time Pooerroeth was no longer the base of the English name of the site. Two European men working for the community set it up for cattle operations and, later, as a detention centre. During this process it had become 'Cattle Camp'.

One of the most distasteful moments I ever had at Cape Keerweer, which is just south of Pooerroeth, was when conversing with a non-Aboriginal fisherman whose family had established itself illegally on the mud flats of the lower Kirke. He blithely referred to all the fishing spots and creeks he was using by entirely new, English, and banal names. Having not long mapped the same places and recorded their real names - and virtually none apart from the Kirke itself and Cape Keerweer had any other known names according to official maps I wondered if I were witnessing the beginning of the end. This small settlement was later removed on orders of the local council.

Not far away are what have become increasingly known, even to the local people, as 'Big Lake' and 'Small Lake' - imaginative names again. 'Small Lake' is now the preferred name it seems, although it was earlier known even to the missionaries as Munpun, more accurately the name of a base camp site on its shores. More properly it is known in its own estate's language as Uthuk Eelen (Small Milky Way) or Weenem Eelen (Small Lawyer Cane). Just south of it is Uthuk Aweyn (Big Milky Way), also known as Weenem Aweyn (Big Lawyer Cane), but it is almost always now known as Big Lake."

There are cases where the Wik equivalents of opaque site names are also opaque and clearly old, for example, Thokali (in earlier records thus, and also 'Dugally', probably an Andjingith name, no longer used $)=$ Thoekel $($ Wik-Elkenh $)=$ Thukel $($ Wik-Mungkan $)$. The last of these is possibly a borrowing from Wik-Elken which has been on the coast a lot longer than Wik-Mungkan. But in fact one hears 'Love River' being used in the region more even than the lingua franca's Thukel.

Many site names are compounds which contain a translatable morpheme and an opaque one, and are thus perhaps old compounds, or a new compound incorporating an old word (for example, Yagalmungkanh?) or snatches of mythic phrase (cf. Pulthalpempang?), so I am not sure how to count these in terms of any attempt to quantify the semantic tendencies of Wik placenames. Should they score a half in each category or one in each?

\section{WHAT DOES 'UNTRANSLATABLE' MEAN?}

There is a halfway house even within this particular set, namely those site names that contain an obviously translatable element plus one that looks like a contraction or archaic version of a typical site-name verb, a class in which I include for the Wik area -sits, -sees, -camps, -lies, -stands. But these 'contracted' or 'archaic' descriptions are the linguist's deductions, not something offered by an informant, at least in a number of cases.

Furthermore, where we have failed to elicit an answer to a direct question about meaning and cannot find the word(s) in our dictionaries, we cannot be sure that the word was not simply a word we did not know but could have been told about, or an uncommon term such as the name for a minor species, a remembered archaism, or one of those Wik synonymous doublets that is only used in the Big Language register. We may thus be wrongly counting the

11 Paired sites like this occur elsewhere, for example the Thiikanen Eelen and Thiikanen Aweyn (Small Island, Big Island) of the Love River estuary, and the Yaal Eelen and Yaal Aweyn (Small Freshwater Stream, Big Freshwater Stream) of the banks of the Kirke River estuary. 
term as being simply opaque (that is, to our informants as well as to ourselves) when (to somebody) it was actually transparent at the time.

Another snare for the unwary here is that the northern Wik languages have all undergone neutralisation of unstressed vowels and final vowel loss, so there are many monosyllables, and homophones abound. Without an informant's reaction one might make the wrong translation of what appears to be a word from the language, or perhaps identify an ancient and opaque word as a modern and meaningful one. The danger of this increases with the shortness and phonological simplicity of the word, monosyllables that lack consonant clusters being dangerous above all other words. And with an informant's reaction as to translatability one would still always be worried by the possibility of folk-etymology and word-play.

\section{LINGUISTIC PREHISTORY}

An added difficulty is that when people have succeeded to estates formerly held by people of a different language, they have clearly neither kept all their predecessors' names for sites nor replaced them wholesale, in at least all the cases I have had time to look at. Near the coast, in the Norman-Archer River region and south to Love River, and in a case or two further south beyond there, are many ancient names which have retained their pronunciations even though they conflict with the sound systems of the dominant local languages, especially the lingua franca Wik-Mungkan.

Different sites within the same estate may thus be named in quite distinct languages, two at least. This is easily established on phonological grounds, the commonest being that names in the area north of Archer River often reflect the presence of a voiced/voiceless stop series (for example, Waager, Thaadh, Chejedem, Wobeb). These voiced stops are not found in northern Wik languages, only southern ones originally spoken far from this area. But they are retained in Wik-Mungkan and other northern Wik varieties when occurring in placenames north of Archer River.

Pre-stopped nasals (for example, Mbang, often now pronounced Bang), rhoticised apicals (Katra), consonant clusters such as $/ \mathrm{mr} /$ or $/ \mathrm{kl}$ ( for example, Upumren, Amran, Intheklok), all impermissible in any Wik language, also occur in this area north of the Archer. There is even some historical evidence of sibilants in these northern placenames (for example, 'Towesie', 'Kumsinmong ${ }^{\prime 12}$ ), another non-Wik feature, and there is a striking frequency of occurrence of site names beginning in $/ \mathrm{r}-/$ (six cases, as against one from the whole of the Wik region south of it; for example, Rugiy, Ruchuw, Rowenem, Renanun). There are also site names north of the Archer that reflect more than the standard five or six vowel positions of the different Wik languages, such as Raethepen, and Eygegen-laem. These, like the phonologically aberrant Yaad near 'Small Lake', which is unusual for being in an area long associated in historical times with a northern Wik variety not a northern Paman one, would appear to reflect the retention of names from some predecessor northern Paman language. ${ }^{13}$

12 See map in MacKenzie (1981:213).

13 There is mythological, ritual and oral historical evidence that a northern Paman language was, perhaps 150 years ago, the language of the estate which lies on the north side of the Kirke River estuary, but it has long been affiliated to a Wik language. Yaad is in the next estate north ('Small Lake'). There seems to have been a general northerly linguistic shift towards Wik language varieties going on for some time in recent prehistory between the Kirke and the Archer. 
Typically this situation is true of estates that are still regarded as being formally identified with the older and more phonologically aberrant language, even if it is no longer fluently spoken. But it also applies to one or two estates where language shift has meant that the language of the owners no longer matches, in phonological structure, the language of a certain number of the names of the sites they own.

I do not think this uneven retention of ancient names of differing phonologies is merely a case of linguistic flexibility among living people, although the deep-seated multilingualism of the area has probably contributed greatly to it. One factor in retention of the voiced-voiceless contrast north of Aurukun may be that some Wik languages also have it, even though they are the southern ones (the Kugu Nganhcara subgroup). But even in the northernmost Wik languages there is non-phonemic voicing. Examples include Wik-Ngathan eelen [e:dn], nganent [ngand], waj (emphatic version of way), and ideophones such as chub! (entered water), pubbbbb! (Story Shark's tail beating water) and dhrrrrrr! (went off quickly). ${ }^{14}$

These occur in a language with a decidedly fortis and voiceless approach to its only phonemic stop series under most conditions. Wik-Mungkan is even more fortis and aspirated in attack when it comes to stops. ${ }^{15}$ It is in a dialect chain with the Kugu Nganhcara varieties. ${ }^{16}$ And it may be stretching things a bit but I am also inclined to think that the arrival of English may have had an effect on the retention of older placenames in the northern area - after all, a voiced-voiceless stop distinction, the [tc] sequence, fricatives and words beginning with [ $[-]$, are common in English.

It is now a problem as to whether or not the older names themselves are opaque - as they always are to people who now do not know that former language - or whether they are translatable using, for example, Ken Hale's dictionary of Linngithigh. ${ }^{17}$ And such names that might have been translatable by old people whose own languages were Wik ones, but who were polyglots with some knowledge of northern Paman varieties, back in the 1970s, may now be quite untranslatable by their grandchildren who remain fluent only in one or more Wik varieties. There may now also be loss of translatability simply on grounds of sheer erosion of specialised lexical knowledge within languages that continue to be spoken.

For a while I thought that it followed from the above that the greater the historical stability of the relation between language variant and clan estate, the greater the homogeneity of the source-language for the site names in the estate, and thus, perhaps, the greater the semantic transparency of the site names, all other things being equal.

$\overline{14}$ Note also the dorso-velar fricative in $[\chi p]$, citation form $/ \mathrm{kap} /$, 'falling down'. Northern Paman languages include at least some with fricatives.

is This raises the interesting question as to why Wik-Mungkan is so unlike most other Aboriginal languages in this way. That is, the usual pattern is that where there is no phonemic voicing contrast, one may expect a tendency not only towards complementary distribution of voiced and voiceless allophones but also towards free variation between them under certain conditions (for example, word-initially, intervocalically). But in Wik-Mungkan /pam/ in isolation is always [pam(a)] never *[bam(a)], /wik/ in isolation is never */wig/, and so on. I would like to advance the idea that Wik-Mungkan's strongly voiceless and fortis stops may be a relational and areal phenomenon - that is, interaction with speakers of languages which do have the contrast may have pushed Wik-Mungkan towards avoiding its superficial appearance. Note also that where such a contrast has evolved anywhere in Cape York Peninsula, as far as I am aware it is always the voiced series that is innovative, deriving from intervocalic nasals, single stops following long vowels, and so on, and the voiceless series retains its basic 'original' character, unless lenited to corresponding semivowels and so on.

16 See Smith and Johnson (2000).

17 Hale (1997). 
I am now not so sure about the stability of the language/estate relationship being likely to result in greater transparency of site names, all other things being equal. A long period of great stability would probably result in a continual reduction of many site names to the status of being opaque. Thus opacity of site names can be treated as a likely index of in situ time depth of the language variety of the site name, but not necessarily of that of the language currently prevailing in either the identity or the daily usage of those who claim the sites. Where the preceding language and an incoming one have the same phonological character, the difficulty of sorting out what is old versus what is merely (until recently) foreign is a very great one.

\section{TRANSLATABLE MODIFIERS OF PLACENAMES}

In the Wik area many placenames contain a clearly translatable reference to the feature that is being named. Prominent among these names are those translatable as 'point $+X$ ', 'creek $+X$ ', 'river $+X$ ', 'well $+X$ ' and 'swamp $+X$ '. ${ }^{18}$ Use of these feature generics may be optional in some cases, but where they specify a subpart or focal point of a site they have a clear and useful function. The use of preposed generics is not unique to placenames. The Wik languages are typically very consistent in classifying everything by the use of generics such as those translatable as 'meat animal', 'vegetable food', 'tree', 'person' and so on. In a few cases the site feature generic is post-posed, as in Wayingk Thiikanen 'Wayingk Island', actually a raised scrub on the island Wayingk, and Merrek Ngamp 'Merrek River'. The latter is a mangrove-lined waterway joining the main Kirke River channel to the large Kirke estuary, and is quite short. This device is distinct from the naming of main rivers. Modest stretches of such rivers may be named, typically from the mouth and upstream for a few kilometres, using the name of a site at the mouth and modifying it by preposing, not post-posing, a word for 'river', as in Ngamp Thew-en 'Lower Kirke River'. ${ }^{9}$

Other distinctions between places may be made using post-posed topographical modifiers, examples of which I provide below. These particular systems clearly reflect a notion of a core referent for the site name, plus a set of one or more derivative or pendant applications of the site name to nearby features. The question as to why one feature is a core referent and another is a derivative one seems mainly to be answered by the use of such sites for different camping and foraging purposes: a base camp is likely to be a core site name referent, while an associated day-shade area or 'dinner camp' may have a name derivative from that of the base

18 There are also cases of 'poison ground $+X$ ' and a very large number of names which specify that a site is a totemic centre ('Story Place'), the term for the latter usually being postposed as in Wiykath Eemoeth ('Child Story Place', Wik-Ngathan) or Pach Aw ('Star Story Place', Wik-Mungkan), although a small number of totemic site names are compounds with aw-as the first stem, for example, Awe-chereng 'Greed Story Place' (cher $=$ greed), but this is more likely to refer to 'plenty' in cases where, as in the instance of Awe-chereng, the language of the site's estate has /aw/ for 'plenty' and not for 'totemic centre'. Many totemic site names end in $-n h i(i) n$ or $-n y i(i) i n$, depending on language variety and degree of archaism, which is fairly evidently a reflex of the verb 'to sit'. This is not the place to enter into a full analysis of Wik placenames, however, so their other structural and semantic aspects await further study.

19 For much of the early and mid-20th century the lower Kirke was called $Y u$ 'engk after a site nearby, and for a time this became the 'Yonka River' of mission records. This usage has declined, the reasons being obscure. It may be relevant that the site $Y u$ 'engk is now some distance from the river mouth, which could well have moved over recent decades. 
camp. In some cases the core referent is a totemic centre rather than a habitation site perse.

The approach to this aspect of site naming rests on a logic derived from the specific geography involved. For example, along the coast north of the Kirke River there is a pericoastal dune system bearing Indo-Malaysian aquifer vine thickets which offer a superabundance of food and other resources such as wells, plus a sandy environment for clean camping, and huge shade trees, the latter doubling as rain shelters beneath which wet season huts were formerly constructed. The core site name referents along this part of the coast generally occur in this woodland environment, and a core site name $(X)$ in this environment may be further specified as ' $\mathrm{X}$ on-top'. Adjacent to the east is a flood plain with grasslands and mainly ephemeral water bodies. The core site $X$ is thus physically above both environments to its east and west, hence the modifier 'on-top'. If there are salt flats to the east of the site, the inland extension of the core site name may be ' $\mathrm{X}$ saltpan'. A day-shade on the beach to the west of a core site, usually a mature Casuarina tree or two, will often be called ' $X$ beach', and a swamp to the east of the core site may be called ' $X$ swamp'. North of the Kirke, again, there may be two 'on-top' core sites, $\mathrm{X}$ and $\mathrm{Y}$, from which only a single beach day shade would be visited, and the latter may be selectively named ' $X$ beach'. ${ }^{20}$

However, south of Kirke River, where the woodland strip is narrow and closer to the beach, and there are swamps but no flood plains to the immediate east, the core site may be called ' $\mathrm{X}$ (swamp)' ${ }^{21}$ and ' $\mathrm{X}$ beach' is its western extension. Where the Kirke estuary reaches right to the narrow coastal woodland the core site may be specified as ' $X$ (outside)', i.e. on the edge of an open expanse of water, ${ }^{22}$ and its western extension may be called ' $\mathrm{X}$ beach'.

Just north of Knox River we see a different logic, although one still consistent with the influence of patterns of economy and physiography on nomenclature. There, the dune woodland occurs only in patches and at a considerable walking distance from the beach. In this environment the core sites are in the woodland patches and near lagoons, and the relevant beach sites to their west are called ' $\mathrm{X}$ road', a reflection of their status as the end points of substantial forays from base camps.

A single site name may apply to two opposed banks of a watercourse. The distinct places may be specified using cardinal directions, ' $X$ north side', ' $X$ south side'. The same directional distinction may also be made between sub-areas within a single large named feature such as the northern head of the mouth of the Kirke River, which is subdivided into Thew-en Wunkenh Kungkem and Thew-en Wunkenh Thiipem ('Thew-en north side, Thew-en south side'). These are both on the same side of the river, however.

A minor feature such as a small swamp or lesser watercourse which is near a focal site may be named using the core site name plus either a cardinal directional term such as ' $\mathrm{X}$ east side', or may be specified using a relative directional and distance-indicating term such as

20 Note that all these modifiers and the head word remain uninflected.

21 Parentheses indicate optionality.

22 The European section of Aurukun village was for many years referred to also as 'outside', but for different reasons. This term was also once standard usage for references to the world beyond the Wik domain. Cairns, for example, was yuun (outside). 
Wik-Ngathan um-wetherr, literally 'facing-midway', hence 'X um-wetherr', 'midway or part-way between $\mathrm{X}$ and the topic location'. ${ }^{23}$

There are cases where two adjacent places are referred to using the same core site name plus modifier(s) but where the relevant sites fall into different clan estates. Thus estate definitions are at essence place-based rather than named-site-based.

\section{DEATH AND SITE NAMES}

How do people refer to a place when the name is tabooed? Actually this occurs as a reasonably constant factor, for example when a placename sounds like or is the same as that of a recently deceased person, or in extreme cases is a place merely strongly associated with a person who has recently died.

A few years ago a senior Wik man died in a dinghy accident near Aurukun. His outstation was known as Stony Crossing, the preferred name, and I doubt that many local people now could give an Aboriginal name for the place. Anyhow, when I got there soon afterwards, some people at least were avoiding not only his first name but also any reference to Stony Crossing as such. Instead they referred to the outstation in Wik-Mungkan, the lingua franca, as nhamperring. Nhamp is 'name', and nhamperriy was the substitute term for the name of a recently deceased female. Males were kootemat. ${ }^{24} \mathrm{I}$ had not come across nhamperring before but $-r r$ is a politeness suffix occasionally used on personal pronouns in Wik-Ngathan, (for example, nhunterr second person singular nominative), $-n g$ is locative case in Wik-Mungkan, and my interpretation of nhamperring is that it is probably a bereavement cover-term for unmentionable placenames.

In a reverse kind of way, placenames are good substitutes for people, if one adds something distinctive, for example, 'head fell at [placename]', i.e. an unnamed or unnameable person who died at a certain place.

Places and people always imply each other in such a culture. If one has to avoid a site name because it resembles the name of a recently deceased person, or conjures up that person, it may be that one of the advantages of having site names that are translatable, or if opaque then substitutable, would be that one is able to refer to the site and yet avoid giving offence.

\section{SAMPLES OF PATTERN}

In spite of all the caveats entered into earlier in this paper, as a quick and rough exercise I have looked at site name translatability for three non-contiguous areas in the Wik region south of the Archer River, namely estate 29 of the Small Archer River, estate 1 on the mouth of Love River, and estate 6 just inland from Cape Keerweer. This is not a comprehensive sample because no southern or truly inland estates were examined, and as a proportion of all site names recorded between the Embley and Edward Rivers the ones examined here probably only amount to about 5 per cent. These figures are also qualified by the fact that $I$ have not

23 Some 34 site names in the database begin with $U m+$, but with primary stress being placed on the following lexeme these are not in such combinations single phonological words. In the case of tum-wetherr primary word stress is on the $u m$.

24 These usages are now archaic, being both replaced in the 20th century by thaapich, which functions very much like kummanara, kumunjayi or kwementyaye etc. of Central Australia, and is a loan word from a northern Paman language. 
had time to use the relevant published dictionaries and unpublished data to do any checking of existing translations in the site database. The translatability figures would probably rise if I did so, but in any case the figures came out like this:

\begin{tabular}{|cccccr|}
\hline ESTATE & TRANSLATABLE & OPAQUE & NOT SURE & $\begin{array}{c}\text { ONE NAME TR., } \\
\text { ONE NOT }\end{array}$ & TOTAL \\
\hline 29 & 12.0 & 18.0 & 0.0 & 0.0 & 30.0 \\
1 & 37.0 & 57.0 & 7.0 & 0.0 & 101.0 \\
6 & 18.0 & 27.0 & 3.0 & 3.0 & 51.0 \\
average & 22.3 & 34.0 & 3.3 & 1.0 & 60.6 \\
$\%$ & 36.8 & 56.1 & 5.4 & 1.6 & 99.9 \\
\hline
\end{tabular}

\section{REFERENCES}

Hale, Kenneth, 1997, A Linngithigh vocabulary. In Darrell Tryon and Michael Walsh, eds, Boundary Rider: essays in honour of Geoffrey O'Grady, 209-246. Canberra: Pacific Linguistics.

MacKenzie, G., 1981, Aurukun Diary. Melbourne: The Aldersgate Press.

Smith, Ian and Steve Johnson, 2000, Kugu Nganhcara. In R.M.W. Dixon and B.J. Blake, eds, Handbook of Australian Languages, vol.5, 355-489. Melbourne: Oxford University Press.

Sutton, Peter, 1978, Wik: Aboriginal society, territory and language at Cape Keerweer, Cape York Peninsula, Australia. PhD thesis, University of Queensland.

- 1995, Wik-Ngathan Dictionary. Adelaide: Caitlin Press.

- 1997, Wik Native Title: anthropological overview [Word-processed 68pp.]. This has the following appendices:

Sutton, Peter (comp.), 1997, Appendix 1: Wik estates [33pp. and map].

Sutton, Peter (comp.), 1997, Appendix 2: Wik clans [68pp.].

Sutton, Peter, David Martin and John von Sturmer, 1997, Appendix 3: Supplementary Site Report [231pp.].

Sutton, Peter, David Martin and John von Sturmer, 1997, Appendix 4: Site Maps [12 GIS-generated A3 maps].

Sutton, Peter, 1997, Appendix 5: Languages [28pp.].

Martin, David and Peter Sutton, 1997, Appendix 6 [13 sample genealogies, genealogy database printouts].

Hale, Kenneth, 1997, Appendix 7: Hale Report [79pp.]

Cribb, Roger, 1997, Appendix 8: Archaeology of Cape York Peninsula and the Wik Claim Area [79pp.]. 
Hunter, Philip (with assistance by Rosalind Kidd and Regina Ganter), 1997, Appendix 9: Historical Document Extracts 1606 to 1970 [212pp.].

Sutton, P., D. Martin, J. von Sturmer, R. Cribb and A. Chase, 1990, Aak: Aboriginal estates and clans between the Embley and Edward Rivers, Cape York Peninsula. Adelaide:

South Australian Museum. [Restricted desktop publication; word-processed and bound, 1000pp. x 25 copies]

Von Sturmer, J.R., 1978, The Wik Region: economy, territoriality and totemism in western Cape York Peninsula, north Queensland. PhD thesis, University of Queensland. 